\title{
口研究所通信 $\mathbf{\square}$
}

\section{H 21 年度 一般公開のお知らせ}

労働安全衛生総合研究所では研究施設の無料一般公開を 次のとおり行います。

詳細は，研究所のホームページをご覧下さい。

HPアドレス

\section{: http://www.jniosh.go.jp/announce/2009/open09/}

<働く人の安全に関する研究施設公開 $>$

内容 : ○職場における災害の防止に関する研究施設見学 機械、建設、化学、電気、人間工学、温熱の各実 験室

○公開実験

○最近の研究成果のポスター展示版

日時：平成 21 年 4 月 15 日（水）

$13: 30 \sim 16: 30$ (受付終了 16:00)

注）この時間内で随時参加が可能です。

場所：労働安全衛生総合研究所 清瀬研究施設

干 204-0024 東京都清瀬市梅園 1-4-6

アクセス方法 :

西武池袋線清瀬駅下車南口バス乗り場 2 番線乗車

5 分「東京病院北」下車 1 分

申込み先: E-mail kokai2009@s.jniosh.go.jpまたは

FAX 042-491-7846

問合せ先 : TEL 042-491-4512（一般公開担当）
＜働く人の健康に関する研究施設公開 $>$

内容：○講演「健康な眠りと目ざめ」

○研究施設見学 音響実験室・振動実験室・電子顕 微鏡室・病理学実験室

○体験コーナー「DNAをみよう」など

○最近の研究成果のポスター展示 など

日時：平成 21 年 4 月 12 日（日）

午前の部 $10: 00 \sim 12: 30$ (受付開始 $9: 30$ )

午後の部 $14: 00 \sim 16: 30$ (受付開始 $13: 30$ )

注) 午前の部と午後の部は同じコースとなります。

場所：労働安全衛生総合研究所 登戸研究施設

干 214-8585 川崎市多摩区長尾 6-21-1 アクセス方法 :

方法1：小田急線・JR 南武線登戸駅下車

川崎市バス登 05 系統す心゙て ( 菅生車庫行きなど )

「五所塚」下車徒歩 7 分

方法2: 小田急線向ヶ丘遊園駅下車

東急バス向 01 系統 梶ヶ谷行き「五所塚」下車 徒歩 7 分

申込み先 : E-mail kokai2009@h.jniosh.go.jp または

FAX 044-865-6124（参加人数を明記）

問合せ先 : TEL 044-865-6111（一般公開担当）

注意事項 :

○当日受付は、午前の部は $10 ： 00$, 午後の部は $14 ： 00$ までにお願い致します。

○実験室が狭いため、参加者多数の場合は、お断りする ことがあります。

○確実にご覧いただくために、事前申し込みをお願い致 します。

\section{所内表彰}

1）研究所の調査・研究業務に多大な貢献をした者 研究企画調整部 前田 節雄 建設安全研究グループ 豊澤 康男
2）若手研究員として多大な貢献をした者

国際情報・労衝衛生研究振興センター 高橋 正也 電気安全研究グループ 市川 紀充 作業条件適応研究グループ 東郷 史治 